\title{
Genetic variability studies in response to drought under different water regimes in muskmelon (Cucumis melo $\mathrm{L}$.)
}

\author{
Sheshnath Mishra ${ }^{1}$, A. K. Sharma ${ }^{2}$ and Vishwanath Sharma ${ }^{3}$ \\ ${ }^{1 *}$ Division of Vegetable Science, ICAR- Indian Agricultural Research Institute, New Delhi-110012, INDIA \\ ${ }^{2}$ Department of Plant Breeding and Genetics, College of Agriculture, Swami Keshwanand Rajasthan Agricultural \\ University (SKRAU), Bikaner-334006 (Rajasthan), INDIA \\ ${ }^{3}$ Division of Seed Science and Technology, Indian Agricultural Research Institute, New Delhi-110012, INDIA \\ *Corresponding Email: cool_ajm_121@yahoo.co.in
}

Received: October 10, 2016; Revised received: April 7, 2017; Accepted: August 20, 2017

\begin{abstract}
A set of 40 genotypes of muskmelon (Cucumis melo L.) were evaluated in a randomized block design with two replications under different water regimes during summer 2012 at the agriculture research station Beechwal, Bikaner, Rajasthan, India to study genetic variability among the traits to determine selection criteria for breeding programmes for fruit yield and related characters. The results reported that drought stress caused reduction in fruit yield and most of the characters studied. Significant variations for all the characters were found under different water regimes (non-stress, $50 \%$ and 25\%). High genotypic (GCV) and phenotypic (PCV) coefficient of variations were observed for fruit yield per plant, fruit weight per plant, vine length and proline content in non-stress, $50 \%$ and $25 \%$ water stress conditions respectively. High estimates of heritability along with high genetic advance as percentage of mean over the characters was recorded for fruit weight $(128.79,164.05$, and 161.15), proline content (42.50, 72.86 and 69.26$)$ and fruit yield per plant $(149.61,186.91$ and 184.12) in both the non-stress and stress conditions. This shows that these traits were under the control of additive genetic effects. Therefore, it was concluded that selection for these traits should lead rapid genetic improvement of the material.
\end{abstract}

Keywords: Genetic advance, Heritability, Muskmelon, Variability, Water regimes

\section{INTRODUCTION}

Muskmelon is a commercially important vegetable species of cucurbitaceae (Potekar et al., 2014) family. In India, it is grown in arid and semi arid region on riverbed as well as field conditions. It is one of the most important summer crop due to its high nutritive and medicinal value and sweetness (Reddy et al., 2013). Muskmelons are insect pollinated and cross pollinated crop so high genetic diversity present within plant population. India is known as second centre of origin of muskmelon and diverse forms are found in fruit shape, size and color (Choudhary et al., 2011). Therefore, the diverse genotypes of muskmelon were studied on the present investigation for accessing different morpho-physiological biochemical parameters related to fruit yield in order to derive more useful information under irrigated and drought conditions.

Study of genetic variability having breeding material in hand is primary importance in any crop breeding programme for improvement in yield (Ibrahim, 2012). Genetic improvement can be made by combing suitable morpho-physiological and biochemical traits in desired agronomic background. Breeding for drought tolerance in muskmelon genotypes require understanding of the morpho-physiological and biochemical re- sponses of muskmelon to drought stress which will help in identifying traits to be used as selection criteria for improving the yield (Kumar et al., 2012). Therefore, it becomes necessary to partition the observed phenotypic variability of various traits into its heritable and non-heritable components for exploiting inherent variability and further selection among genotypes with suitable genetic parameters such as phenotypic and genotypic coefficient of variation, heritability, genetic advance and genetic advance as percent of mean.

Drought leads to increasing the yield losses in crops worldwide (Martinez et al., 2007; Bastos et al., 2011; Fulda et al., 2011; Kusvuran, 2012).). Global climate change by industrial revolution will affect crop productivity particularly that of vegetables including melon by frequent occurrence of drought (McCarthy and IPC, 2001, Ibrahim, 2012). According to FAOSTAT (2011), melons production was approximately 126 million tons among total 609 million tons production of all fruits in the year 2009. A forty percent increase in the production of melons is required for a growing population over the next three decades. The introduction of varied elite melon varieties that are competent of producing more fruit yield and will be critically important to achieving sustainable fruits production security. This is also must required the reorien- 
tation of the cultivation strategies of the resulting high yielding, well adapted, and less input in cultivation of melons. Therefore, the present study was undertaken to evaluate the germplasm for various traits and to study the extent of genetic variability in the material of muskmelon under drought stresses in order to develop new varieties to sustain food production under adverse climate condition.

\section{MATERIALS AND METHODS}

Fourty genotypes of muskmelons (Table 4) collected from NAIP project, Biotechnology centre, Bikaner were used as genetic material for the present study. All genotype were grown and evaluated under different water regimes at "Agriculture Research Station", Swami Keshvanand Rajasthan Agricultural University (SKRAU), Beechwal, Bikaner (Rajasthan) in summer season 2012. Each of the three experiments was designed in randomized block design with two replications. The cultural packages of practice were used to general programme of muskmelon cultivation. Drought condition were started after 40 DAS and created by one half to that of irrigated crop i.e. missing alternate irrigation in $S_{1}$ stress condition and quarter to that of irrigated crop in $\mathrm{S}_{2}$ condition. Genotypes were sown in a plot size of $4 \mathrm{~m}$ length and $3 \mathrm{~m}$ width. Three to five seeds were sown per hole with $80 \mathrm{~cm}$ spacing between holes in furrow of $50 \mathrm{~cm}$. After seed sowing at 15-20 days, the extra plants were rouged out except one to two healthy seedlings. A row to row spacing of $3 \mathrm{~m}$ and plant to plant spacing of $80 \mathrm{~cm}$ was adopted.

Three plants were randomly selected from each plot and observations were recorded on days to first female flowering, number of fruits per plant, fruit weight, vine length, number of branches per plant, relative water content, leaf chlorophyll content, proline content, total sugar content and fruit yield per plant. The mean value was used for statistical analysis. The Phenotypic variances were calculated according to Comstock and Robinson (1952). Coefficient of variations was calculated by the formulae suggested by Burton (1952). Genotypic variances, heritability in broad sense and expected genetic advance for each character was calculated according to the formulae suggested by Johnson et al. (1955).

\section{RESULTS AND DISCUSSION}

The analysis of variance showed significant variation for all the characters in different water regimes (nonstress, $50 \%$ and $25 \%$ ) under study, indicating presence of sufficient variability in the material studied, which provides ample scope for selection superior and desired genotypes by the plant breeder. Similar observations have been found by Torkadi et al. (2007) for days taken to first female flowering, number of fruits per vine and weight of fruits per vine; Rashidi and Seyfi (2007) for number of fruits per plant and fruit weight;
Rad et al. (2010) for sugar percentage, fruit weight and fruit yield ; Keshavarzpour et al. (2011) for fruit yield, number of fruits per plant and fruit weight; Reddy et al. (2013) for vine length, number of primary branches per vine, days to appearance of first pistillate flower, average fruit weight and fruit yield per plant; Ibrahim and Ramadan (2013) for stem length, number of primary branches per plant, days to first female flower appearance, fruit weight, number of fruits per plant and total fruit yield per plant attributes respectively in muskmelon (Cucumis melo L.). Genetic variability is important in order to realize response to selection pressure. It has also been pointed out that the magnitude of genetic variability present in base population of any crop species is essential in crop improvement and must be exploited by plant breeder for yield improvement. The estimates of variability parameters under different water regimes are shown in (Tables 1-3) respectively. In general, the magnitude of phenotypic coefficient of variation $(\mathrm{PCV})$ were higher than the corresponding genotypic coefficient of variation (GCV) under different water regimes for all the ten characters under study as also observed by Reddy et al. (2013) for traits like vine length, number of primary branches per vine, days to appearance to first pistillate flower, fruit weight, number of fruits per vine and fruit yield per plants in muskmelon.

Among the characters observed, high genotypic and phenotypic coefficient of variations were noticed for fruit yield per plant, fruit weight per plant, vine length, total sugar and proline content in non-stress, 50\% and $25 \%$ water stress conditions. Since genotypic coefficient of variation compares the relative amount of variability among the attributes, it could, therefore, be deduced that fruit yield per plant, fruit weight per plant, vine length and proline content had higher amount of exploitable genetic variability among the attributes. It also signifies that there is greater potential for favorable advance in selection in these attributes when compared to others. These results were in accordance with those of other workers for most of the characters as reported by Pandey et al., (2005) for fruit weight and fruit yield per plant; Rakhi and Rajamony, (2005) for fruit yield per plant and fruit weight per plant; Tomar et al. (2008) for fruit weight, fruit yield per plant and total soluble sugar; Choudhary et al., (2011) for yield per plant and fruit weight; Ibrahim (2012) for total fruit yield per plant and fruit weight in muskmelon. Other parameters such as number of branches per vine and number of fruits per plant had moderate coefficient of genotypic variation, indicating the heritable portion of the total variation existing in the population.

The lowest GCV and PCV were observed for days to first female flowering, total chlorophyll content and relative leaf water content in all the three water regimes, which indicated that selection, might not be effective for these characters as low GCV and PCV are 
Sheshnath Mishra et al. / J. Appl. \& Nat. Sci. 9 (3): 1744 -1750 (2017)

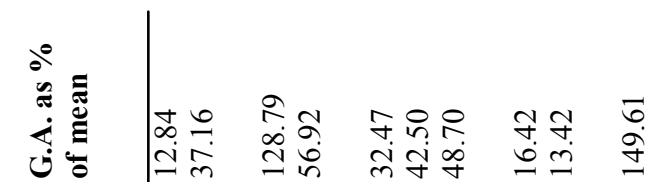

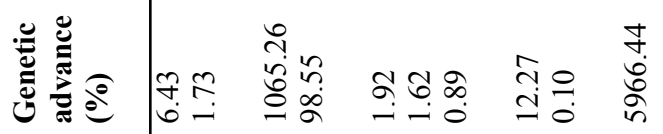

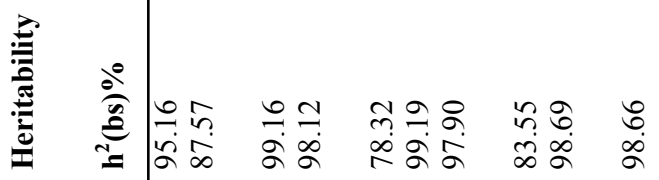

च 己

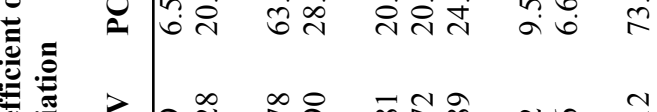

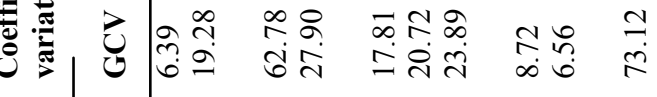

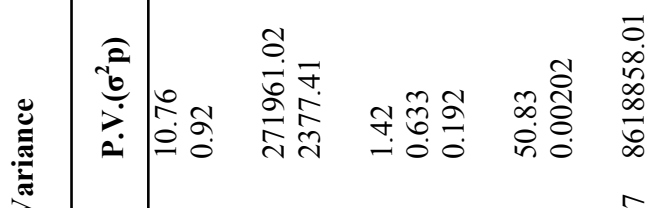

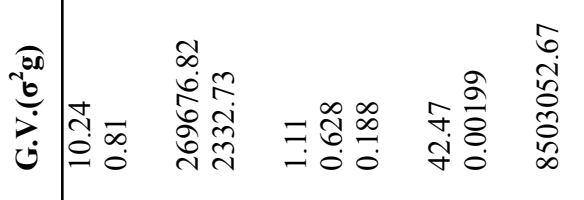

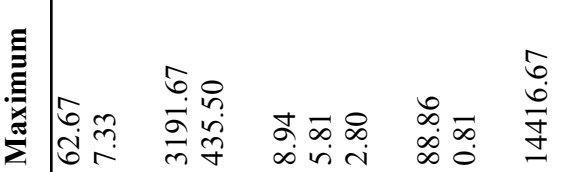

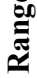

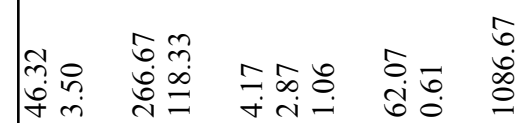

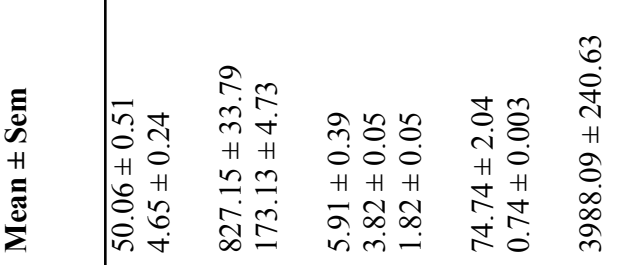

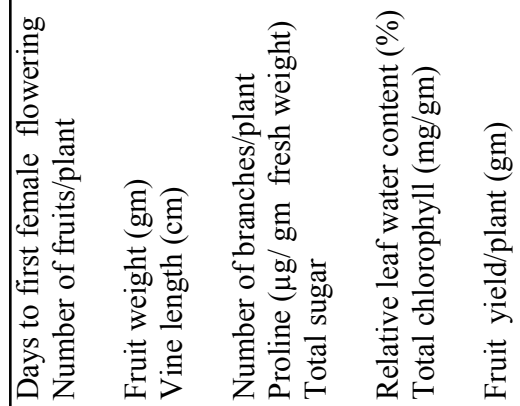
$\stackrel{\circ}{1746}$

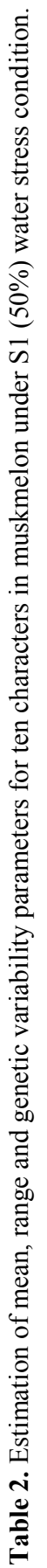

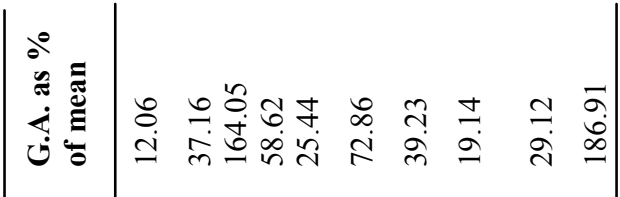

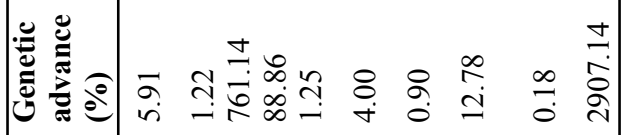

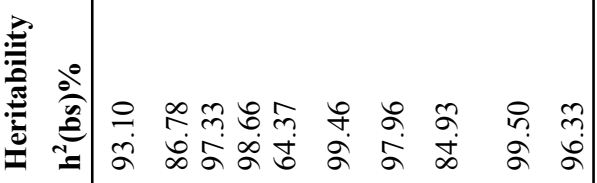

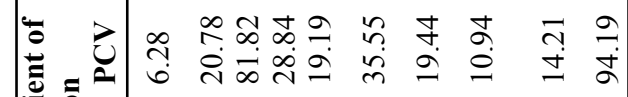

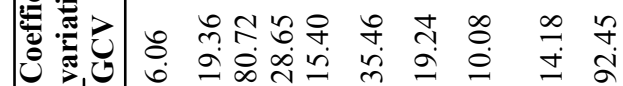

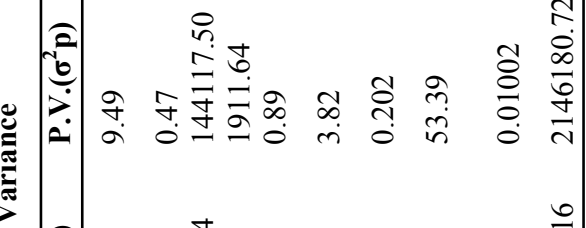

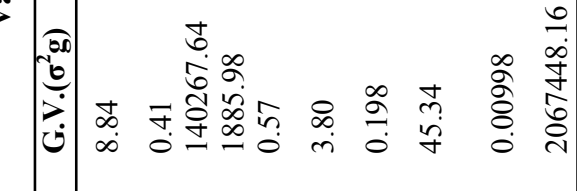
施 尊

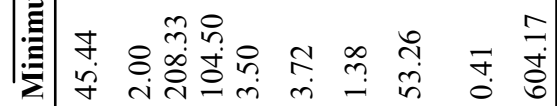

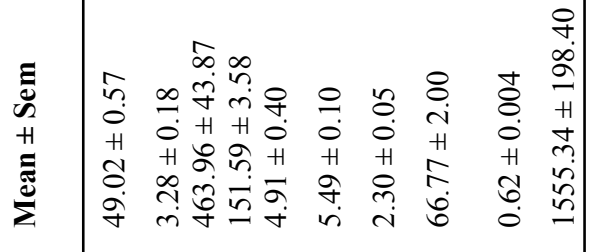

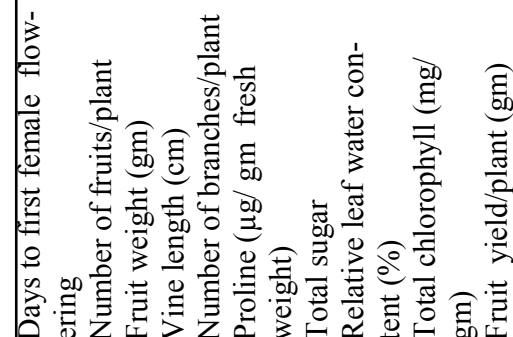




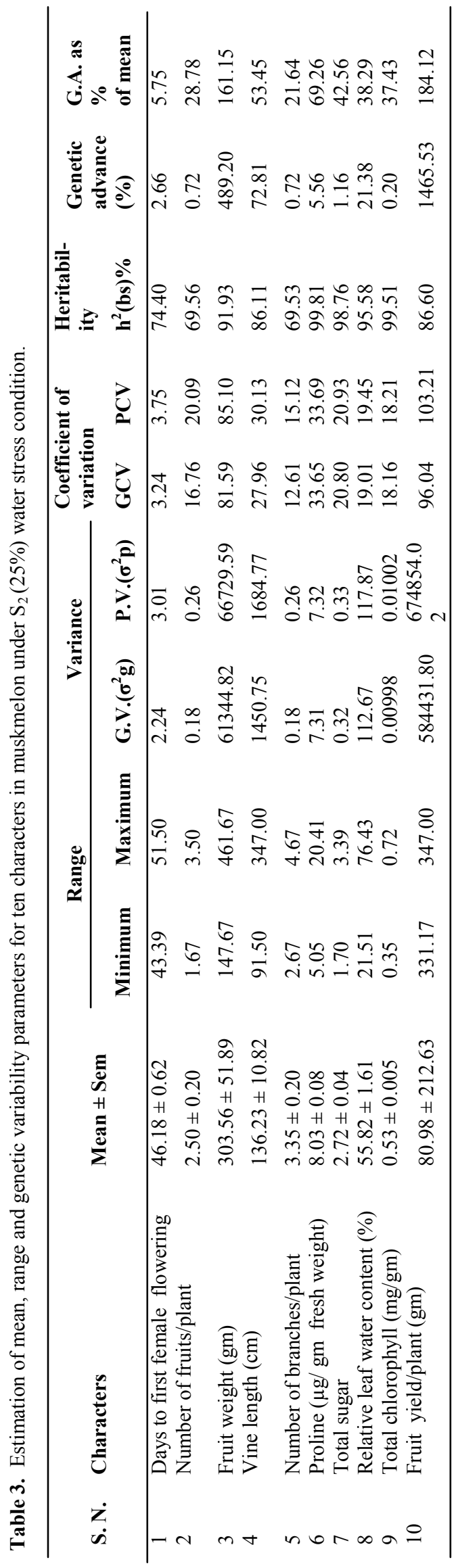

Table 4. List of muskmelon genotypes used for present investigation.

\begin{tabular}{llll}
\hline S. N. & Genotype & S. N. & Genotype \\
\hline 1 & ArkaJeeth & 21 & IIHR-RM-652 \\
2 & DurgapuraMadhu & 22 & IIHR-RM-653 \\
3 & EC-564755 & 23 & IIHR-RM-655 \\
4 & IIHR-GPW-12 & 24 & IIHR-RM-659 \\
5 & IIHR-GPW-15 & 25 & IIHR-RM-660 \\
6 & GYNO & 26 & IIHR-RM-662 \\
7 & Hara Madhu & 27 & IIHR-RM-663 \\
8 & MM-06-662 & 28 & IIHR-RM-671 \\
9 & MG-5 & 29 & IIHR-RM-673 \\
10 & MS-1 & 30 & IIHR-RM-675 \\
11 & Punjab-Sunehri & 31 & IIHR-RM-680 \\
12 & PusaMadhuras & 32 & IIHR-RM-681 \\
13 & IIHR-RM-43 & 33 & IIHR-RM-699 \\
14 & IIHR-RM-190 & 34 & IIHR-RM-708 \\
15 & IIHR-RM-352 & 35 & IIHR-RM-712 \\
16 & IIHR-RM-387 & 36 & IIHR-RM-716 \\
17 & IIHR-RM-604 & 37 & IIHR-RM-718 \\
18 & IIHR-RM-616-1 & 38 & IIHR-RM-719 \\
19 & IIHR-RM-619 & 39 & IIHR-RM-720 \\
20 & IIHR-RM-624 & 40 & EC-564754 \\
\hline
\end{tabular}

directly proportional to presence of low variability and thus limiting the scope for further improvement through selection. These results are in agreement with the findings of Sahni et al., (1987) in ridge gourd; Singh et al., (1989) in muskmelon; Prasad and Singh (1992) in cucumber; Pandey et al., (2009) in snap melon and George (1981) for days to first female flowering in ash gourd. The estimation of genotypic (GCV) and phenotypic (PCV) coefficients of variation exhibited small differences for most of the characters, under non-stress and $50 \%$ water stress conditions revealing that environmental effects were not great importance on the expression of these traits under non-stress and $50 \%$ water stress conditions. Thus, the phenotypic and genotypic coefficient of variation followed a similar trend indicating less influence of environmental variation as reported by earlier workers (Baye, 2002 in Vernonia galameusis var ethiopica; Sood et al., 2011 in bell peper; Emeka and Ojimelukwe 2012 in papaya and Emeka et al., 2013 in Egusi melon). However, for the traits, e.g., fruit yield per plant, fruit weight per plant, vine length and proline content, the phenotypic coefficient of variations were more in $25 \%$ water stress condition revealing more influence of environment. Heritability estimates includes measure of transmission of traits from one generation to the next and gives the consistency in the performance of progeny in succeeding generations. It depends mainly on the magnitude of heritable portion of variation. Estimation of heritability works as a predictive instrument in exercising the reliability of phenotypic value, so helpful for the breeder in selection for traits. Thus, heritability is a key genetic parameter in quantitative genetic because it determines response to selection. Heritability in broad sense may be defined as the proportion of phenotypic variance that is attributable to an effect of 
whole genotype, comprising the sum of additive, dominance and epistatic effects (Nyquist 1991; Falconer and Mackay 1996) whereas the narrow sense heritability may be defined as the proportion of phenotypic variance among individuals in a population that is due to heritable genetic effects. In plant breeding there are different designs and observations units are quite diverse ranging from individual plants to mean of genotypes tested across wide range of environments in designed experiments. Specifically, large sets of genotypes are tested in designs and narrow sense heritability definition does not apply in such cases. Hence broad sense heritability has more importance in plant breeding. If heritability of a character is high $(>80 \%)$, it suggests that character is under genetic control. Hence, selection for such characters should be fairly easy. This is because there would be close correspondence between genotypic and phenotypic variation due to relatively smaller contribution of the environment to the phenotype, but for a character with low heritability $(<20 \%)$, selection may be considerably difficult or virtually impractical due to masking effect of environment on the genotypic effect. High estimate of heritability was obtained for proline content (99.19, 99.46 and 99.81), fruit weight (99.16, 97.33 and 91.93), total chlorophyll content $(98.69,99.50$ and 99.51), fruit yield per plant $(98.66,96.33$ and 86.60$)$, vine length (98.12, 98.66 and 86.11), total sugar (97.90, 97.96 and 98.76) and relative leaf water content $(83.55,84.93$ and 95.58) in both non-stress and stress conditions. The high estimated heritability values indicating that phenotypic selection for these traits could be highly efficient. In muskmelon, high heritability for most of these characters was reported by Parmar and Lal (2005). Similar results of high heritability was also observed for other cucurbitaceous crops by Rajendran and Thamburaj (1994) in watermelon for total yield per plant; Saikia and Bora, (1995) in cucumber for vine length, number of fruits per vine and total yield per plant; Prasad and Singh (1992) in cucumber and Prasad and Singh (1990) in sponge gourd for vine length and fruit weight; Rastogi and Aryadeep (1990) in cucumber for number of fruits per vine, fruit weight and total yield per plant; Srivastava and Srivastava (1976) in bitter gourd and AbdEl-Salam et al., (2010) in snake guard for fruit yield per plant. Heritability along with the genetic advance is more important than heritability alone in predicting the resultant effect of selecting best individual genotype because, it inform of the presence of additive gene effects. The genetic advance is important indicator of the progress that can be expected as a result of exercising selection of the pertinent genotypes (Sood et al., 2011). Heritability values coupled with genetic advance have more practical importance in selection based on phenotypic performance. So, genetic advance should be considered associated with heritability incoherent selection breeding programme. Relative comparison of heritability along with genetic advance as percentage of mean over the characters indicated that characters viz. fruit weight, proline content and fruit yield per plant had high heritability estimates along with high genetic advance (\% of mean) in both the non-stress and stress conditions. High $h^{2}$ and high GA as recorded in the present investigation were also reported by several researchers such as George, (1981) in ash gourd for mean fruit weight; Rakhi and Rajamony (2005); Torkadi et al. (2007); Tomar et al. (2008); Reddy et al. (2013) in melon for fruit yield per plant. Genotypic variations for such traits are probably due to high additive gene effects (additive type of gene actions) and least influenced by the environments. Direct simple phenotypic selection based on such traits likely to be more effective for improvement and hence these traits offer good promise for future breeding programme using simple breeding methods. High heritability coupled with low genetic advance exhibited by traits viz. days to first female flowering, relative water content and total chlorophyll content. Heritability for these traits was due to nonadditive gene effects (non-additive type of gene actions). This indicates that hybridization followed by selection will be effective for genetic improvement of these traits because direct selection for these traits will be no effective. Similar results were also obtained by Rao et al., (1999) in cucumber, Samadia (2007) in round melon and Pandey et al., (2005), Choudhary et al., (2011), Reddy et al., (2013) in muskmelon for days to first female flowering.

\section{Conclusion}

The data in this study indicated possibility of improvement in muskmelon genotypes by selection for fruit weight, fruit yield per plant and proline content under water stress conditions. Based on the high heritability and high genetic advance as shown by these traits, it may be concluded that phenotypic expression of these traits are controlled by additive genes. Hence, need to be given more emphasis in selection. High heritability and low genetic advance of characters indicates nonadditive gene actions suggesting the possibility of genetic improvement through hybridization breeding programmes. High heritability and low genetic advance was observed for days to first female flowering, relative water content and total chlorophyll content in all the three water regimes. The study revealed that breeder should adopt suitable breeding methodology to utilize both additive and non additive gene effects simultaneously for developing variety and hybrid under water stress conditions in muskmelon.

\section{REFERENCES}

AbdEl-Salam MMM, El-Demardash, IS., and Hussein, AH (2010). Phenotypic Stability Analysis, Heritability and Protein Patterns of snake Cucumber Genotypes. $J$. 
Amer. Sci., 6(12):503-507.

Bastos EA, Nascimento SPD, Silva EMD, Freire FR and Gomide, RL (2011). Identification of cowpea genotypes for drought tolerance. Revista Ciencia Agronomica, 42: 100-107.

Baye T (2002). Genotypic and phenotypic variability in Vernonia galameusis var ethiopica germplasm collected from Eastern Ethopia. J. Agric. Sci., 139:161-168.

Burton G W (1952). Qunntitative inheritance of grasses.Proc. $6^{\text {th }}$ International Grass Land Cong., 1:277- 282.

Choudhary H, Ram HH and Singh DK (2011). Genetic variability study in muskmelon. Progr. Hort., 43(2):231-233.

Comstock RE and Robinson HF (1952). Genetic parameters, their estimation and significance. Proceeding of $6^{\text {th }}$ International Grassland Congress, 1:284-291.

Emeka NG and Ojimelukwe P (2012). Variability in proximate, mineral and vitamin contents of Carica papaya L. leaves fruits pulp and seeds. Int. J. Med. Arom. Plants, 2:90-96.

Emeka NG, Maria Okoro, Justin OM and Agbo CU (2013). Assessment of phenotypic variability, heritable components and character association in Egusi melon (Citrullis vulgaris) Thumb) Matsum and Nakai accessions. Amer.- Eurasian J. Agric and Env. Sci., 13 (7):961-966.

FAOSTAT, (2011). FAO statistical databases data sets. Available at http://faostat.fao.org/.

Falconer D S and Mackay T F C (1996). An Introduction to Quantitative Genetics, Ed. 4. Prentice Hall, London.

Fulda S, Mikkat S, Stegmann H, Horn R (2011). Physiology and proteomics of drought stress acclimation in sunflower (Helianthus annuus L.). Plant Biol., 13: 632642.

George TE (1981). Biometrical studies in ash gourd (Benincasahispida (Thumb.) Cogn). M.Sc. (Ag.) Thesis, Kerala Agricultural University, Trissur.

Ibrahim (2012). Variability, heritability and genetic advance in Egyptian sweet melon (Cucumis melo var. aegyp tiacus L.) under water stress conditions. Int. J. Plant Breeding and Genetics, 6(4):238-244.

Ibrahim EA and Ramadan YA (2013). Correlation and path coefficient analysis in sweet melon (Cucumis melo var. aegyptiacus L.) under irrigated and drought stress conditions. Bio. Sci., 16(13):610-613.

Johnson HW, Robinson HF and Comstock E (1955). Estimates of genetic and environment variability in Soyabean. Agron. J.,47:314-318.

Kumar R, Solankey SS and Singh M (2012). Breeding for drought tolerance in vegetables. Vegetable Sci., 39 (1):1-15.

Keshavarzpour F. and Rashidi M. (2011). Response of crop yield and yield components of cantaloupe to drought stress. World applied sci. J., 15(3): 382-385.

Kusvuran S (2012). Effects of drought and salt stresses on growth, stomatal conductance, leaf water and osmotic potentials of melon genotypes (Cucumis melo L.). Afr. J. Agric. Res. 7(5): 775-781.

Martinez ML, Intralawan A, Vazquez G, Parez-Magueo O, Sutton P and Landgrave R (2007). The coast of our world: ecological, economical and social importance. Ecol. Econ., 63:254-272.

McCarthy JJ and IPCC (2001). Climate Change: Impacts, adaption and vulnerability: Contribution of working group 11 to Third Assessment Report of The Intergovernmental Panel on Climate Change. Cambridge Uni- versity Press, UK, ISBN-13:9780521015004, Pages: 1032 .

Nyquist W E (1991). Estimation of heritability and prediction of selection response in plant populations. Crit. Rev. Plant Sci. 10: 235-322.

Pandey S., Rai M and Singh B (2005). Genetic variability and character association in muskmelon (Cucumis melo L.). Indian J. Plant Genet. Resour. 18(2): 212-216.

Pandey S., Kashya SK, Jha A, Choudhary BR, Kumar S, Singh DK and Rai M (2009). Inter-trait association and genetic variability assessment in Snapmelon (Cucumis melo var. momordica). Indian J. Plant Genet. Resour. 22(2): 113-116.

Potekar SV, Nagre PK and Sawant SN (2014). Genetic variability study in muskmelon (Cucumis melo L.). International J. Tropic. Agric. 32(3-4):349-351.

Parmar AM and Lal T (2005). Variability studies in melon. Res. on crops, 6(2):314-317.

Prasad VSRK and Singh DP (1990). Genetic variability and heritability studies in sponge gourd (Luffa cylindrical) A note. Haryana J. Hort. Sci., 19(1-2):222-224.

Prasad VSRK and Singh DP (1992). Estimates of heritability, genetic advance and association between yield and its components in cucumber. Indian J. Hort., 49: 62-69.

Rad MRN, Allahhdoo M and Fanaei HR (2010). Study of some yield traits relationship in melon (Cucumis melo L.) germplasm gene bank of Iran by correlation and factor analysis. Trakia J. Sci., 8(1):27-32.

Rajendran PC and Thamburaj S (1994). Genetic variability in biometrical traits in watermelon. Indian J. Agric. Sci., 64(1): 5-8

Rakhi R and Rajamony L (2005). Variability, heritability and genetic advance in landraces of culinary melon (Cucumis melo L.). J. Tropical Agric., 43 (1-2):79-82.

Rashidi M and Seyfi K (2007). The effects of water stress on yield and yield components of cantaloupe (Cucumis melo SP.). Int. J. Agri. Biol., 9(2): 271-273

Rastogi KB and Aryadeep (1990). A note on interrelationship between yield and important plant characters of cucumber. Vegetable Science, 17(1): 102-104

Rao ES,Verma VK and Munshi AD (1999). Genetic variability in cucumber (Cucumis sativus L.). Indian J. Plant Genetic Resour.,12:201-204

Reddy BPK, Begum H, Sunil N and Reddy MT (2013). Variance component analysis of quantitative traits in muskmelon (Cucumis melo L.). Trakia J. Sci., 2: 118-124.

Sahni GP, Singh RK and Saha BC (1987). Genotypic and phenotypic variability, heritability in ridge gourd. Indian J. Agril. Sci., 55(99):666-668.

Saikia J, Shadeque and Bora GC (1995). Genetic studies in cucumber. Haryana J. Hort. Sci., 24(1): 73-76.

Samadia DK (2007). Studies on genetic variability and scope of improvement in round melon under hot arid conditions. Indian J. Hort. 64(1):58-62.

Singh MJ, Randhawa KS and Lal T (1989). Genetic analysis for maturity and plant characteristics in muskmelon. Veg. Sci., 16: 181-184.

Sood S, Kumar N, Chandel KS and Sharma P (2011). Determination of genetic variation for morphological and yield traits in bell peper (Capsicum annum var grossum). Indian J. Agric. Sci., 81:590-594.

Srivastava VK and Srivastava LS (1976). Genetic parameters correlation coefficient and path coefficient analysis for 
Sheshnath Mishra et al. / J. Appl. \& Nat. Sci. 9 (3): 1744 -1750 (2017)

bitter gourd. Indian J. Hort., 33(1): 66-70.

Tomar RS, Kulkarni GU, Kakade DK, Patel AD and Acharya RR (2008). Genetic variability, correlation and path analysis in muskmelon (Cucumis melo L.). Asian J.
Hort., 3(1):158-161.

Torkadi SS, Musmade AM, and Mangrave KK (2007). Genetic variability studies in muskmelon (Cucumis melo L.). J. Soils Crop, 17:308-311. 